\title{
POŻEGNAĆ BEREHYNIE. LITERACKIE PRÓBY DEMITOLOGIZACJI STEREOTYPOWEGO OBRAZU UKRAINKI NA WYBRANYCH PRZYKŁADACH UKRAIŃSKIEJ PROZY KOBIECEJ PO 1991 ROKU
}

\author{
ANIELA RADECKA ${ }^{1}$ \\ (Uniwersytet Wrocławski)
}

\begin{abstract}
Słowa kluczowe: ukraińska proza kobieca, tożsamość społeczno-kulturowa, kobieta jako Inny, postkolonializm, posttotalitaryzm Key words: Ukrainian women's literature, socio-cultural identity, woman as Other, post-colonialism, post-totalitarianism
\end{abstract}

\begin{abstract}
Abstrakt: Aniela Radecka, POŻEGNAĆ BEREHYNIĘ - LITERACKIE PRÓBY DEMITOLOGIZACJI STEREOTYPOWEGO OBRAZU UKRAINKI. WYBRANE PRZYKŁADY ZE WSPÓECZESNEJ UKRAIŃSKIEJ PROZY KOBIECEJ. „PORÓWNANIA” 20, 2017. T. XX, S. 125-134. ISSN 1733-165X. Autorka analizuje zabiegi literackie mające na celu demitologizację figury Berehyni w wybranych powieściach Oksany Zabużko, Sofiji Andruchowycz i Natałki Śniadanko. Postępująca od lat dziewięćdziesiątych $\mathrm{w}$ wysokoartystycznym dyskursie literackim oraz w literaturze środka demitologizacja figury Berehyni jest jednym z najważniejszych elementów procesu (re) konstruowania kobiecej tożsamości społeczno-kulturowej, gdyż zawiera się w tej demitologizacji sprzeciw kobiet wobec zastanej sytuacji. Współczesne autorki dobitnie pokazują, że za symbolem prawdziwej ukraińskiej kobiety kryją się różnorodne jednostki, mające swoje rzeczywiste problemy, doświadczenia i przede wszystkim niemające dotąd prawa do własnej reprezentacji.
\end{abstract}

Abstract: Aniela Radecka, FAREWELL BEREHYNIA - LITERARY ATTEMPTS AT DEMYTHOLOGIZATION OF THE STEREOTYPICAL IMAGE OF UKRAINIAN WOMEN. SELECTED EXAMPLES OF CONTEMPORARY UKRAINIAN WOMEN'S PROSE. "PORÓWNANIA" 20, 2017. Vol. XX, P. 125-134. ISSN 1733-165X. The author analyses the literary treatments aimed at the demythologization of the Berehynia figure in selected novels by Oksana Zabuzhko, Sofija Andrukhovych and Natalka Sniadanko. Progressing from the nineties in a highly artistic literary

1 E-mail: aniela.radecka@gmail.com 
discourse (and also in middle literature) the demythologization of the Berehynia figure is one of the most important elements of the process of the (re)construction of the female socio-cultural identity, as it contains the opposition of women to the existing situation.

Wysiłek, jaki podjęły ukraińskie pisarki, aby zrekonstruować i zreinterpretować kobiecy dyskurs w prozie ukraińskiej po rozpadzie Związku Sowieckiego, stanowił nie lada wyzwanie. Odgórne przerwanie rozwoju ukraińskiego feminizmu i kobiecego pisarstwa przez dyskurs sowietyzmu spowodowało, że pisarki i badaczki po roku 1991 musiały wydobywać na powierzchnię ogólnej świadomości społeczno-kulturowej twórczość swoich poprzedniczek, zaangażować się w spory o istnienie ukraińskiej kobiecej literatury, ruchów kobiecych, feminizmu na terenach ukraińskich itp. Aby kobiece głosy znów mogły być słyszalne na Ukrainie, należało podjąć (jednocześnie) swoistą pracę u podstaw na wielu płaszczyznach - nie tylko literackiej i kulturowej, ale również społecznej oraz politycznej. Prekursorką badań naukowych nad ukraińskim feminizmem była Sołomija Pawłyczko, której badania, nagle przerwane tragiczną śmiercią pod koniec 1999 roku, nadal stanowią ważny element w dyskusji o ukraińskiej literaturze i kulturze. Należy tu wymienić również takie ukraińskie badaczki jak Niła Zborowska, Tamara Hundorowa, Wira Agejewa, Iryna Żerebkina czy amerykańska badaczka ukraińskiego pochodzenia Marian Rubchak. Ostatnia z wymienionych, Rubchak, już od wczesnych lat dziewięćdziesiątych promowała na Ukrainiefeminizm i zwracała uwagę na pozycję kobiety w społeczeństwie ukraińskim. Szereg jej opracowań dotyczy także dekonstrukcji stereotypu Berehyni nie tylko $\mathrm{w}$ literaturze, ale także $\mathrm{w}$ mediach, społeczeństwie i kulturze.

\section{Geneza figury Berehyni}

Rubchak upatruje genezy figury Berehyni w dawnej ukraińskiej mitologii, w której berehyniami nazywano niebezpieczne duchy wody, mające kobiecy wygląd i zamieszkujące brzegi rzek (Rubchak). Berehyni, tzn. Strażniczka Domowego Ogniska, jest symbolem, który zamyka kobietę w ściśle określonych ramach. Uwzględnia on rzekome predyspozycje wrodzone, które nie są niczym innym, jak narzuconymi przez kulturę stereotypami i normami (Filipowicz 230). Do figury Berehyni można porównać postać Matki Polki, określaną przez Halinę Filipowicz jako głęboko antyfeministyczną. Matka Polka otoczona jest $\mathrm{w}$ literaturze porozbiorowej patriotycznym kultem, strzeże tradycji i ciągłości, a eksponowanie kultu tej postaci usprawiedliwia drugorzędny status kobiety w społeczeństwie patriarchalnym (Filipowicz 233).

Upadek przestarzałych, nie tylko pod względem politycznym i gospodarczym, struktur ZSRR wiązał się również z krachem dotychczasowych paradygmatów. Antropolożka Oksana Kiś w artykule Wzorce konstruowania tożsamości genderowej kobiet na wspótczesnej Ukrainie zauważa, że wraz z wydarzeniami z przełomu lat osiemdziesiątych i dziewięćdziesiątych skończył się monopol sowieckiej nad-kobie- 
ty (sowiecka super-zhinka), co w konsekwencji sprowokowało potrzebę określenia nowych wzorców (Kiś 2003: 1).

Zarówno możliwość, jak i potrzeba pojawienia się takowej postaci zrodziła sięw okresie tzw. pieriestrojki, kiedy to sowiecka ideologia, wraz ze swoimi skostniałymi wzorcami (w tym i genderowymi), stała się całkowicie niewystarczająca (Kiś 2006: 4). Polem do rozprzestrzeniania się symbolu Berehyni była w pierwszych latach niepodległości literatura i twórczość między innymi neonarodnickich pisarzy (np. Wasyl Ruban - Berehyni), którzy propagowali postać idealnej kobiety-Ukrainki, obywatelki niepodległego państwa ukraińskiego. Mimo oczywistego eklektyzmu tego symbolu, który zawiera w sobie elementy: archaicznych pogańskich wierzeń w Matkę Ziemię, matriarchatu, chrześcijańskiego kultu Maryi, symboliki zaczerpniętej z folkloru ukraińskiego itd., jest on uważany za immanentny, ponadczasowy i odwieczny rdzeń kobiecej tożsamości Ukrainek (Kiś 2003: 1). W imię obrony symbolu Berehyni, potwierdzającego jakoby nadrzędne miejsce kobiety w ukraińskiej kulturze i społeczeństwie, łatwo było negować wszelkie próby emancypacji i walki o równouprawnienie $w$ latach dziewięćdziesiątych minionego stulecia (choć, prawdę powiedziawszy, ów proceder nie stracił na swej aktualności również i dzisiaj).

W artykule Czy na Ukrainie jest możliwy feminizm? Pawłyczko podjęła kwestię równouprawnienia, jakie rzekomo realny socjalizm przyniósł ukraińskim kobietom, a którego de facto był on parodią (Pawłyczko 167). Dlatego też w latach dziewięćdziesiątych trzeba było zmagać się z kolejnym, tym razem neonarodnickim i antykolonialnym mitem - powrotu ukraińskiej kobiety do domu, co w rzeczywistości było nie tylko gloryfikacją roli matki i Berehyni - jako tych jedynie słusznych ról prawdziwej Ukrainki - ale i renesansem patriarchatu. W konsekwencji dla odradzającego się ukraińskiego feminizmu zdobycie w przestrzeni publicznej swojego miejsca i wypracowanie własnego, tj. niezależnego od optyki patriarchalnej, dyskursu, okazało się w dwójnasób trudne. Jednak sukcesywnie postępująca od lat dziewięćdziesiątych w wysokoartystycznym ukraińskim dyskursie literackim (w dużej mierze również $w$ tzw. literaturze środka) demitologizacja figury Berehyni jest jednym z najważniejszych elementów procesu (re)konstruowania kobiecej tożsamości społeczno-kulturowej, albowiem zawiera się w niej jaskrawy sprzeciw kobiet wobec zastanej sytuacji. Współczesne autorki dobitnie pokazują, że za symbolem prawdziwej ukraińskiej kobiety kryją się zróżnicowane podmioty kobiece, mające swoje rzeczywiste problemy, doświadczenia i przede wszystkim niemające dotąd prawa do własnej reprezentacji w literaturze (Radecka 258).

\section{Literackie próby demitologizacji stereotypu Berehyni}

Proza kobieca konstruowana jest z pozycji outsidera w danym społeczeństwie - autorka to Inny, który ma dokładnie przy pisane miejsce i rolę do wykonania. Ko- 
lejne pokolenia pisarek muszą ponownie udowadniać wartość swojej twórczości, często źle interpretowanej i niedocenianej przez wiodący dyskurs (Chruślińska, Zabużko 210), nierzadko pozostającej poza oficjalnym kanonem. W obliczu mnogości autorek i utworów współczesnej prozy kobiecej na Ukrainie wybór trzech pisarek i jedynie kilku tekstów był niezwykle trudny. Przedstawicielką pierwszego pokolenia tworzących po upadku ZSRR jest nie tylko Oksana Zabużko, ale także między innymi Jewhenia Kononenko czy Hałyna Pahutiak. Nie mniej płodną artystycznie generacją pozostają pisarki urodzone pod koniec istnienia sowieckiego reżimu, tj. Natałka Śniadanko, Sofija Andruchowycz, Irena Karpa czy Tania Malarczuk.

Proponowana w niniejszym artykule analiza wybranych powieści autorstwa Oksany Zabużko, Sofiji Andruchowycz i Natałki Śniadanko ukazuje próbę zmagania się pisarek z narzuconą im rolą oraz miejscem $\mathrm{w}$ ukraińskim społeczeństwie i narodzie (w sensie politycznym, co jest niezwykle ważną kwestią), które wyrażone są w figurze Berehyni, stanowiącej konstrukt ukraińskiego dyskursu patriarchalnego.

W literaturze ukraińskiej końca XX wieku prekursorskim głosem feministycznym jest powieść Badania terenowe nad ukraińskim seksem autorstwa Zabużko. Jej twórczość, zarówno poezja, proza, jak i erudycyjne eseje o ukraińskiej literaturze i kulturze, stanowią nieodłączną część ukraińskiego dyskursu literackiego i krytycznoliterackiego. Badania terenowe... to mikropowieść, która w momencie ukazania się (1996) wywołała natychmiastowe reakcje krytyków, w ogromnej części negatywne, wręcz agresywne. Jednym $z$ aspektów tego utworu jest feminizm, uważany przez niektórych krytyków, zarówno wtedy, jak i dzisiaj, za zdradę interesów narodowych (Fiłonenko 22). Zdaniem Agejewej, Badania terenowe... zainicjowały liczne dyskusje na temat kobiecego pisarstwa oraz przyczyn nałożenia przez kulturę patriarchalną tabu na kobiece ciało i doświadczenia seksualne kobiet (Agejewa 112). Tematyka podjęta przez Zabużko w Badaniach... wywołała burzliwe wręcz dyskusje na temat granic otwartości w literaturze, nienormatywnej leksyki w dziele literackim, narodowej i postkolonialnej problematyki w powieści, opisywania aktu seksualnego i w końcu samego feminizmu obecnego w tymże dziele (Fiłonenko 25). Główna bohaterka powieści wymawia wręcz niewybaczalne dla krytyków i neonarodników słowa:

No ale niechby kto w końcu wyjaśnił: po kiego diabła było przychodzić na świat jako kobieta (w dodatku na Ukrainie) - z tą kurewską zależnością, wmontowaną $\mathrm{w}$ ciało jak bomba z opóźnionym zapłonem, z tą niesamodzielnością, z potrzebą przetapiania się na wilgotną, rozciapcianą glinę, wtłoczoną w glebę [...] (Zabużko 2008: 21, podkr. A.R.).

W powyższym fragmencie widoczna jest podwójna zależność ukraińskich kobiet: są częścią narodu skolonizowanego przez Imperium Rosyjskie i poddanego totalitaryzacji przez ZSRR, a oprócz tego pozostają zależne od rodzimych mężczyzn. 
Wewnętrzny bunt bohaterki Badań terenowych ... przeciwko takiej sytuacji, wyrażony w formie herstorycznego monologu, to próba powiedzenia sobie i uwierzenia, że ma się prawo do tego buntu, do posiadania własnych pragnień, do poszukiwania tożsamości, do zmiany zastanej sytuacji. Jest to sprzeczne z założeniami propagatorów figury Berehyni, gdyż równolegle z rozpowszechnianiem tego symbolu odbywała się idealizacja spuścizny historycznej pod hasłem odrodzenia ukraińskiej duchowości i ideałów. Utrzymywano, że od wieków w ukraińskim społeczeństwie istniało równouprawnienie kobiet i mężczyzn, a ich role są uświęcone przez historię i samego Boga, z czego, jak można się domyślić, kobieta w tym układzie to matka, żona, gospodyni domowa, kontynuatorka tradycji, strażniczka duchowości (Kiś 2003: 4). W przekonaniu Kiś, jest to kolejne potwierdzenie podziału sfer aktywności i samorealizacji: prywatnej (kobiecej) i publicznej (męskiej) (Kiś 2003: 5). Bohaterka Zabużko czuje ciężar spoczywającej na niej odpowiedzialności, wie, że jako intelektualistka, osoba świadoma ukraińskiej spuścizny memorialno-historycznej, jest w innej sytuacji niż pozostali, w tym przypadku mężczyźni:

[...] przez całe życie! - zawodowa ukrainizatorka [...], kiedyś nasza niepodległa, czy raczej ta, co jeszcze-nie-zginęła, jeśli do tej pory nie zginie, powinna wprowadzić jakieś specjalne odznaczenie - za liczbę zukrainizowanych łożkomiejsc [...] (Zabużko 2008: 43).

Protagonistka Badań terenowych za pomocą tego, co prywatne i intymne, opisała sferę publiczną, tj. narodową. Tego typu zabieg nie mieścił się $\mathrm{w}$ propagowanych przez neonarodników wzorcach kulturowo-literackich, skwapliwie stroniących od cielesności i seksualności (zwłaszcza kobiecej - sic!), nienormatywnego języka i sposobu wypowiedzi, a przede wszystkim unikających prób przepracowania ukraińskich postkolonialno-posttotalitarnych traum, które w przypadku Badań terenowych... stanowią powieściowe clou:

[...] bo mamę to wszystko omijało, mama w ogóle była oziębła, jakżeby inaczej, nieprzenikalna, czarne szkło spawalnicze [...] - a jaka miała być, jeśli nie oziębła, dziecko głodu [...] karmione podebranymi z pola kłoskami [...] (Zabużko 2008: 189-190).

[...] ojca, który odsiedział swoje sześć lat jeszcze „za Stalina”, przez calutkie życie popędzał, jak wiewiórkę w lesie, kompleks „recydywy” - drugiego aresztu nikt nie wytrzymywał [...] (Zabużko 2008: 87).

Zabużko starała się więc przekonać swoich czytelników, iż dziesięcioleciami przekazywana z pokolenia na pokolenie traumatogenna spuścizna sowiecka, będąca konsekwencją wyniszczania narodów i jednostek przez struktury imperium, winna zostać przepracowana przez społeczeństwo, a nie tylko zastępowana nowymi wartościami i paradygmatami. 
Mit Berehyni to w pierwszej kolejności mit Obywatelki-Matki, do czego przyczyniło się utożsamienie patriotyzmu z kultem macierzyństwa, którego celem jest wychowanie kolejnych pokoleń ukraińskich obywateli (Kiś 2003: 7). Wymaga się od kobiet całkowitego poświęcenia na rzecz rodziny, a co za tym idzie na rzecz narodu - obywatelski obowiązek budowania nowego, niezależnego państwa oraz odrodzenia ukraińskiego narodu stał się obowiązkiem kobiet (Kiś 2003: 6).

Jednak figura Berehyni łączy się także i z innym stereotypem: narodu ukraińskiego jako ofiary. Zabużko w rozmowie/wywiadzie-rzece z Izą Chruślińską przyznaje, że w Badaniach terenowych... zawarła swoje własne gorzkie wyrastanie z narodowo-romantycznych juwenaliów, wywodzących się jeszcze z XIX wieku - to na nich w dużej mierze opierała się ukraińska kultura nieradzieckiego typu (Chruślińska, Zabużko 139). Żywotność obu tych stereotypów świadczy o niedojrzałości ukraińskiego narodu i braku możliwości wzięcia odpowiedzialności za podejmowane działania w zakresie odbudowy państwowości i społeczeństwa. Jak zauważa Agnieszka Mrozik:

w dyskursie narodowym/nacjonalistycznym to k o b i e ty pełnią funkcję biologicznych reproduktorek członków danej społeczności i gwarantek ",czystości narodu/rasy”, K o bi e ta zaś jest znakiem kultury tejże wspólnoty, a także symboliczną reprezentantką ciała i kondycji narodu. Kobiece ciało służy jednocześnie do reprodukcji (biologicznej) i reprezentacji (symbolicznej) - nie ma w tym sprzeczności. Kobieta jest wyłącznie ciałem, w całości bądź we fragmentach wykorzystywanym do celów politycznych, zmieniających się $\mathrm{w}$ zależności od momentu historycznego, w jakim aktualnie znajduje się naród (Mrozik 113-114, podkr. A.M.).

W Berehyni postrzega się czy nie jedyną szansę na odrodzenie ukraińskiej kobiecości, zrujnowanej przez sowiecką władzę (Kiś 2006: 6), czego konsekwencją jest upolitycznienie kobiecej cielesności. Nie dziwi więc, że Zabużko oskarżono o zamach na społeczną moralność, a raczej o zamach na aureolę świętości otaczającą wyobrażenie ukraińskiej kobiety (Agejewa 113). Berehyni owszem, ma rodzić i wychowywać kolejne pokolenia obywateli, jednak jest przy tym całkowicie aseksualna i pozbawiona władzy nad swoim ciałem - kobieta zostaje sprowadzona do funkcji rozrodczej.

Pozornie wysoka pozycja kobiety w społeczeństwie ukraińskim, wyrażona w figurze Berehyni, jest elementem dyskursu patriarchalnego. Aby w pełni ukazać mechanizm dekonstrukcji stereotypu w najnowszej ukraińskiej prozie kobiecej, należy włączyć w obszar badań prozę pisarek urodzonych po 1980 roku. Wchodziły one w dojrzałość już po odzyskaniu przez Ukrainę niepodległości, co ma niebagatelne znaczenie dla ich twórczości - mogły podróżować na Zachód, konfrontować to, co jest im znane, $\mathrm{z}$ tym co obce, nowe. 
Powieść Andruchowycz Siomga (2007) stanowi studium dojrzewania kobiety, gdzie, podobnie jak u Zabużko, momentami dochodzi do głosu mała dziewczynka. Opowieść głównej bohaterki powieści, Sofiji (autorka nadała protagonistce swoje imię) oparta jest w dużej części na pamięci ciała. Młoda kobieta, której pierwsze doświadczenia $\mathrm{z}$ własną cielesnością i seksualnością przypadają na lata przełomu politycznego, odtwarza wydarzenia z dzieciństwa oraz okresu dojrzewania. Jej światem rządzą emocje i odczucia, a obserwator (zarówno czytelnik, jak i powieściowy podglądacz) widzi:

Przypadki autodestrukcyjnej słabości (kiedy zakopywałam się w pościeli i patrzyłam w sufit nieobecnym wzrokiem, postanawiając porzucić wszelkie starania, pragnąc wyparować, zgnić, uschnąć), napady szaleńczej, zabójczej złości (kiedy ryczałam i rzucałam komputerami i naczyniami [...]), najwścieklejsze histerie (kiedy zanosiłam się płaczem, trzęsłam się, chwytałam ustami powietrze [...]) (Andruchowycz 65-66).

W końcu to także kobieta ma prawo do posiadania i wyrażania uczuć oraz poznawania własnego ciała i jego reakcji. Według Marii Rewakowicz w centrum powieści znajduje się kobieca seksualność (Rewakowicz 1), jednak można mówić tu nie tylko o seksualności, a o cielesności kobiety w ogóle. Ciało funkcjonuje tu, jak ujęła to w kontekście literaturoznawstwa korporalnego Urszula Śmietana, jako centralna kategoria organizująca materię i kształt (soma)tekstu: jest imaginarium, zespołem argumentów i znaczeń, strukturą retoryczną i estetyczną, a także fundamentem tożsamości (Śmietana 169). Skonstruowana przez Andruchowycz kobieca cielesność daleka jest od jej zikonizowanego wyobrażenia, które zajmuje centralne miejsce $\mathrm{w}$ postkolonialnym i posttotalitarnym dyskursie, nadal dominującym na Ukrainie.

Protagonistka Andruchowycz w swoich wspomnieniach przywołuje obrazy przemocy seksualnej stosowanej wobec kobiet i dzieci, a sama powieść kończy się rozczłonkowaniem ciała bohaterki przez mężczyznę, pragnącego przywłaszczyć sobie jej wnętrzności. Jednak okazało się, że poruszenie kwestii przemocy wobec kobiet nie było najważniejsze w interpretacji krytyków - największym skandalem było między innymi bezpośrednie opisywanie intymnych doświadczeń oraz tytuł, Siomga, czyli łosoś, co w języku ukraińskim stanowi eufemizm, określający kobiece narządy płciowe.

Inny ważny utwór w kontekście demitologizacji figury Berehyni to Kolekcja namiętności, czyli przygody młodej Ukrainki (2001) Śniadanko. To powieść o nastolatce, która swoje wchodzenie $w$ kobiecość opisuje przez pryzmat autodoświadczeń zdobytych $\mathrm{w}$ kontaktach z płcią przeciwną: od miłości platonicznej po fizyczną, z których każda, w swoim czasie, odgrywała niezwykle ważną rolę w jej życiu. Ta z pozoru beztroska opowieść o miłosnych przygodach głównej bohaterki ukazuje mentalność rodziny z Ukrainy Zachodniej. Po namiętnościach młodzieńczych i historiach miłosnych z obcokrajowcami przychodzi czas ustatkowania się bohaterki, która wychodzi za mąż, jak przystało na prawdziwa galicjankę, za Ukraińca. Ironiczne 
zakończenie książki w postaci dodatku Małżeństwo z prawdziwa galicjanką. Instrukcja obstugi w sposób karykaturalny ukazuje lwowską mentalność i wyobrażenie o kobiecie, przekazywane z pokolenia na pokolenie:

Prawdziwa galicjanka to przeważnie ucieleśnienie piękna. [...] zgrabna, długowłosa i długonoga, [...]. Jest świętym szatanem lub Bogurodzica smutna, która zeszła z obrazu, jest Jedyna. [...] Każda prawdziwa Galicjanka trzyma się prosto, jej ruchy są płynne, krok dostojny i pełen powagi. [...] Prawdziwa Galicjanka to wspaniała gospodyni, która potrafi przyrządzić nie tylko barszcz, uszka i kutię [...] (Śniadanko 282-284).

W powyższym fragmencie dzięki ironicznemu przerysowaniu cech dziewczyny wychowanej w Galicji (we Lwowie) widać, jak przenikają się ze sobą dwa obrazy, Berehyni, wyidealizowanej, wyniesionej na ołtarze, i Barbie, kobiety-lalki. Takie połączenie dwóch pozornie przeciwstawnych obrazów jest możliwe ze względu na rolę kobiety, która jawi się w tych stereotypach, a jest nią zaspokojenie wymagań mężczyzny.

\section{Wnioski}

Proza Zabużko i Andruchowycz zmierza do reprezentacji doświadczenia, a w takim przypadku nie można pominąć ciała, które staje się dla ludzkiego doświadczenia zasadniczym punktem odniesienia (Dziadek 20). U Śniadanko cielesność i fizyczne kontakty głównej bohaterki z płcią przeciwną są pretekstem do ukazania mentalności i wciąż niezwykle żywych stereotypów dotyczących kobiet ${ }^{2}$.

Mocno zakorzeniony w ukraińskim społeczeństwie stereotyp Berehyni pozwala ignorować nie tylko gorszy status kobiet w ukraińskim społeczeństwie, ale także przemoc wobec nich. Literatura kobieca jako przestrzeń ekspresji twórczej współczesnych ukraińskich autorek pozwala na wyrażenie sprzeciwu wobec paradygmatów narzucanych kobietom. Sprzeciw ten pokazuje, że za każdym uogólnieniem kryje się indywidualna jednostka, która ma swoje pragnienia i potrzeby. W ukraińskich realiach zresztą rola Berehyni najczęściej jest niemożliwa do wypełnienia - kobiety nie mogą poświęcić się w pełni wychowaniu dzieci i prowadzeniu domu, gdyż świadomie czy też zmuszone przez okoliczności podejmują pracę (Kiś 2003: 12), aby utrzymać rodzinę (często za granicą).

Wybrane przeze mnie pisarki i ich powieści to jedynie przykłady demitologizacji figury Berehyni w najnowszej ukraińskiej prozie kobiecej. Jednym z etapów

2 Nie można nie wspomnieć w tym miejscu o Muzeum porzuconych sekretów, swoistym opus magnum Zabużko. Główna bohaterka powieści, Daryna Hoszczyńska, to kobieta walcząca ze stereotypem Berehyni na wszystkie możliwe sposoby - zarówno prywatnie, jak i w sferze zawodowej. Ta niezwykle istotna literacka reprezentacja, ukazująca ewolucję poglądów autorki na przestrzeni czasu, zasługuje jednak na odrębne studium. 
tego procesu jest, zapoczątkowana po upadku Związku Sowieckiego, możliwość reprezentacji kobiet w literaturze, które mogą przemawiać własnym głosem, konstruując herstoryczną narrację. Podejmowana przez nie walka ze stereotypowym postrzeganiem roli kobiety w ukraińskim społeczeństwie świadczy o tym, że kwestia ta pozostaje nadal niezwykle aktualna.

\section{BIBLIOGRAFIA}

Agejewa, Wira. „Kobieta-autor i kobieta-czytelnik we współczesnej literaturze ukraińskiej”. Literatury stowiańskie po roku 1989. Nowe zjawiska, tendencje, perspektywy. Tom II: Feminizm. Red. E. Kraskowska. Warszawa: Wydawnictwo Kolor Plus, 2005. S.106-119.

Andruchowycz, Sofija. Siomga. Przeł. Michał Petryk. Wołowiec: Wydawnictwo Czarne, 2009.

Chruślińska Iza, Zabużko Oksana. Ukraiński palimpsest. Oksana Zabużko w rozmowie z Iza Chruślińską. Wrocław: Wydawnictwo Kolegium Europy Wschodniej, 2013.

Dziadek, Adam. Projekt krytyki somatycznej. Warszawa: Wydawnictwo IBL, 2014.

Filipowicz, Halina. „Przeciw literaturze kobiecej”. Ciało i tekst. Feminizm w literaturoznawstwie - antologia szkiców. Red. A. Nasiłowska. Warszawa: Wydawnictwo IBL, 2001. S. 222-234.

Fiłonenko, Sofija. Koncepciya osobystosti zhinky v ukrains'kyi zhinochyi prozi 90-tyh rokhiv XX stolittia. Kyïv: Vydavnyctvo Aspekt Poligraf, 2006.

Kiś, Oksana. „Modeli konstruiuvannia gendernoi identychnosti zhinky v suchasnii Ukraini”. Yi 27 (2003) Web. 13.09.2016 <http://www.ji.lviv.ua/n27texts/kis.htm>.

Kiś, Oksana. „Koho oberihaye Berehynia, abo Matriarkhat yak cholovichyy vynakhid”. Ya 4(16) (2006). Web. 13.09.2016 <http://social-anthropology.org.ua/publication/statti/koho-oberihaie-berehynia/>.

Mrozik, Agnieszka. Akuszerki transformacji. Kobiety, literatura i władza w Polsce po 1989 roku. Warszawa: Wydawnictwo IBL, 2012.

Pawłyczko, Sołomija. Feminizm: Statti, doslidzhennia, besidy ta interviu. Kyïv: Osnovy, 2002.

Radecka, Aniela. „Zarys prozy kobiecej na Ukrainie po 1991 roku. Rekonesans badawczy”. Posttotalitarny syndrom pokoleniowy w literaturach stowiańskich Europy Środkowej, Wschodniej i Południowo-Wschodniej końca XX-początku XXI wieku w świetle studiów postkolonialnych. Red. A. Matusiak. Wrocław - Poznań: Wydawnictwo Bonami, 2016. S. 253-285.

Rewakowicz, Maria. „Sylni zhinky perezhyvayut' feminizm”. 2012. Web. 16.09.2016 <http://krytyka. $\mathrm{com} / \mathrm{ua} / \mathrm{print} /$ articles/sylni-zhinky-perezhyvayut-feminizm>.

Śmietana, Urszula. „Od écriture féminine do somatekstu”. Przeglad Filozoficzno-Literacki 1 (2003). S. 153-171.

Rubchak, Marian. „Collective Memory as a Device for Constructing a New Gender Myth”. Contemporary Ukraine on the Cultural Map of Europe. Red. L.M.L. Zaleska Onyshkevych, M.G. Rewakowicz. Armonk, New York, London, England: M.E. Sharpe, 2009. S. 139-154.

Śniadanko, Natałka. Kolekcja namiętności, czyli przygody młodej Ukrainki. Przeł. Katarzyna Kotyńska, Renata Rusnak. Wołowiec: Wydawnictwo Czarne, 2004.

Zabużko, Oksana. Badania terenowe nad ukraińskim seksem. Przeł. Katarzyna Kotyńska. Warszawa: Wydawnictwo W.A.B, 2008. 